\title{
Even at the uttermost ends of the Earth: how seabirds telecouple the Beagle Channel with regional and global processes that affect environmental conservation and social-ecological sustainability
}

\author{
Andrea N. Raya Rey ${ }^{1,2}, \underline{\text { J. Cristobal Pizarro }}^{1,3}$ Christopher B. Anderson $^{1,2}$ and Falk Huettmann $^{4}$
}

\begin{abstract}
Human-wildlife dynamics exhibit novel characteristics in the Anthropocene, given the unprecedented degree of globalization that has increased the linkages between habitats and people across space and time. This is largely caused by transnational mobility and migration, international labor, resource markets, and trade. Understanding the relationship between humans and wildlife, and their associated telecoupling processes, helps to promote better management practices and governance for reconciling socioeconomic and conservation interests. Even remote places on the globe exhibit these features. For example, in southern Patagonia's coastal and marine ecosystems, seabirds are not only very abundant and charismatic members of the wildlife community, nowadays, their colonies are a main tourism attraction of global significance, and in the past they were used for consumptive and scientific purposes that also linked the "uttermost ends of the Earth" with distant places. Thus, in this study, we review human-seabird interactions in the iconic Beagle Channel (BC) in the Argentine portion of the Tierra del Fuego Archipelago. We adapted and employed the coupled human and natural systems (CHANS) approach and telecoupling framework to integrate disparate social and biological information and obtain a more holistic understanding of current human-seabird dynamics and trends in the BC. Although our assessment includes the temporal scale of human-seabird relationships, we centered the CHANS and telecoupling analysis on the modern seabird-tourism interaction, focused on the channel's Argentine sector, in which tourism is most intensively developed. Our synthesis of the BC's telecoupled CHANS allowed us to recognize the strong historical local-to-global interactions between both human and natural subsystems and the sharp increase in distance telecoupling during the 20th century. Despite this globalizing trend in seabirds connecting the BC's local ecosystems to distant places, ironically we found few linkages between Argentina and Chile, despite both countries sharing political sovereignty over this single biogeographical unit. Recognizing and studying the telecouplings identified in this study would help multilateral efforts to incorporate the spillover systems (especially with Chile) and sending systems (i.e., transnational tourists' countries of origin) into extant regional policies (e.g., state protected areas) and global initiatives (e.g., the United Nations' sustainable development goals). It would also enable more informed decisions regarding specific proposals based on market-based incentives (e.g., payment for ecosystem services), certification schemes (e.g., Distintivo Onashaga) and participatory approaches (e.g., comanagement of natural resources with local communities). Integrating these scales into the management of the $\mathrm{BC}$ would help ensure that humans continue to enjoy meaningful relationships with this unique and charismatic wildlife and at the same time reinforce responsible tourism as a local-global strategy for sustainable development and global conservation.
\end{abstract}

Key Words: coupled human natural systems (CHANS); human-wildlife interactions; marine wildlife; nature-based tourism management; southern Patagonia; transboundary conservation

\section{INTRODUCTION}

Although humans and other wildlife have always been connected (Steadman 1995), in the Anthropocene (Crutzen 2002), the characteristics and dynamics of these interactions have taken on novel characteristics. The unprecedented degree of globalization increases the number and strength of linkages between species, habitats, and people across space and time, due to transnational human mobility and migration, international labor and resource markets, and worldwide trade (Held et al. 1999). These fluxes, in turn, create a complex network of social and political institutions within and among countries (Adger et al. 2009, Lambin and Meyfroid 2011, Liu et al. 2013), and furthermore, the Internet, social media, and telecommunications empower global networks' ability to reach and influence diverse and distant social and ecological systems (Eakin et al. 2014). As a result, although coupled human and natural systems (CHANS; Liu et al. 2007) have long existed, they increasingly display not only particular, place-based regimes of disturbance and feedbacks between the social and biophysical domains, but also are influenced by and respondent to distant CHANS in a process that has been termed telecoupling (Liu et al. 2013).

Indeed, this phenomenon has become so widespread that now even vast, remote natural areas in high-latitude biomes of both the northern and southern hemispheres are affected by the Anthropocene's novel social-ecological drivers of change (Lewis et al. 2004, Lüdecke 2010, Huettmann 2012). At local and regional scales, resource exploitation (e.g., minerals, energy, fisheries, and timber) can be an important factor that modifies the status and trends of biodiversity and ecosystem services. At the same time, though, these areas are affected simultaneously by planetary forces, such as climate change (Descamps et al. 2017) and biological invasions (Frenot et al. 2005, Ballari et al. 2015). Therefore, although the world's polar and subpolar

${ }^{1}$ Centro Austral de Investigaciones Científicas (CADIC), Consejo Nacional de Investigaciones Científicas y Técnicas (CONICET), Argentina, ${ }^{2}$ Instituto de Ciencias Polares, Ambiente y Recursos Naturales, Universidad Nacional de Tierra del Fuego, Argentina, ${ }^{3}$ Department of Forest Management and Environment. Forest Sciences Faculty, Universidad de Concepción, Chile, ${ }^{4}$ EWHALE lab- Institute of Arctic Biology, Biology \& Wildlife Department, University of Alaska Fairbanks (UAF), Alaska 
biomes are often classified as pristine wilderness (sensu Mittermeier et al. 2003), in fact they are not only under the pressure of sustaining local human population needs (e.g., resources, urbanization, and economic development), but also face novel pressures from globalization, including being top destinations for the international tourism industry (Lück et al. 2010, Huettmann 2012, Tin 2016).

Consequently, studying human-nature interactions is ever more relevant and challenging, even in faraway places and for nonconsumptive uses like tourism. Plus, a CHANS perspective of these phenomena alone is insufficient because they must be understood vis-à-vis their relationships with other systems over large spatial distances (i.e., telecoupling). In this way, new research should be oriented to better inform natural resource management by connecting local-to-global factors of socioeconomic and ecological studies that seek to reconcile nature conservation and human well-being (Carter et al. 2014). In particular, the telecoupling approach helps scholars and managers to identify and assess a system's (or a problem's) components, their interrelationships, feedbacks, and multidirectional flows that would otherwise go unperceived (Liu et al. 2013, Liu 2014, Eakin et al. 2014). In this sense, a more holistic view is required that captures modern global social-ecological realities. To this end, the CHANS (Walker et al. 2004) and telecoupling frameworks (Liu et al. 2013, Eakin et al. 2014) complement one another and are powerful conceptual models to better study and manage biodiversity, ecosystems, and human well-being, especially in the face of rapid changes in their social and ecological drivers.

Described to the West by Anglican missionaries as the "uttermost ends of the Earth" (Bridges 1949), Tierra del Fuego (TDF) is a remote archipelago at the southern tip of the South American continent. Indeed, it is the southernmost landmass outside of Antarctica, and the sub-Antarctic forest and Patagonia steppe ecoregions that cover these islands are identified as two of the world's last remaining wilderness areas (Mittermeier et al. 2003). Building upon this western social imaginary (Moss 2014), TDF has come to belong to an elite group of destinations that claim the title of "end of the world" or "southernmost destination" (Lonely Planet 2016). Nonetheless, in the last century, TDF experienced massive social and ecological transformations, but notwithstanding this fact, in many respects it continues to be considered a wild frontier whose social-ecological complexity has not been fully considered in research or conservation (Rozzi et al. 2012).

For example, the Beagle Channel(BC) is a biogeographical feature that bisects this insular system. It flows in a west-east direction from the Pacific to the Atlantic oceans along the southern coast of TDF Island at about $55^{\circ} \mathrm{S}$ (Argentina and Chile) and the northern coasts of Navarino and Hoste islands (Chile). As a transoceanic shipping passage, a binational political jurisdiction, a historical and cultural landmark, and an iconic natural landscape, the BC is clearly a CHANS with significant singularities and challenges for its integrated study and management (Rozzi et al. 2004). Examining more closely one aspect of the BC's biodiversity, the channel also represents an important ecosystem for bird conservation, and its Argentine portion has been classified as an important bird area (IBA; Di Giacomo et al. 2007). However, this status does not imply any enforceable legal protection. In turn, these birds and their associated marine ecosystem contribute to all four ecosystem service categories delineated by the Millennium Ecosystem Assessment (MEA 2003), including provisioning, regulating, cultural, and supporting services (Whelan et al. 2008, Burdon et al. 2017, Ferreira et al. 2017). Indeed, because of their abundance, diversity, and charisma, seabirds in the BC have been important to humans for millennia (Caviglia 2012), and today, they also constitute the main attraction for an expanding tourism industry for both Argentina and Chile (Raya Rey and Schiavini 2000, Schiavini and Raya Rey 2001, Reyes Arriagada et al. 2015, Nahuelhual et al. 2017). Nature-based tourism offers the potential to preserve biodiversity, diversify the region's economic base, and ultimately help achieve sustainable development that reconciles nature conservation and human well-being (Higham and Lück 2007, Liu et al. 2015, Tin 2016). However, there is currently a lack of conservation research and policies that address the human (e.g., tourism) and natural (e.g., seabirds) components of the $\mathrm{BC}$ together and their relationships with other parts of the world.

We adapt and employ the CHANS and telecoupling frameworks to integrate disparate social and biological information of the BC (Fig. 1), focusing on the Argentine portion in which naturebased tourism is a major economic activity. Specifically, we seek (1) to contextualize today's BC by describing historical changes in the human-seabird relationship from prehistoric times to the 1980s; (2) to identify the major components of the modern human-seabird interaction by placing emphasis on the current relationship via nature-based tourism; and (3) to elucidate linkages with systems beyond the BC's physical and political boundaries by determining the agents, flows, causes, and effects of these relationships. We aim for this contribution to allow not only a better understanding of the trends, patterns, and dynamics of this complex system, but also expect to support local and global sustainability by detecting otherwise unrecognized conservation threats and opportunities that can be incorporated and addressed in both social-ecological investigation and sustainable governance.

Fig. 1. Map of the study area, showing the location of the Beagle Channel and the main cities and human settlements in both its Argentine and Chilean portions.

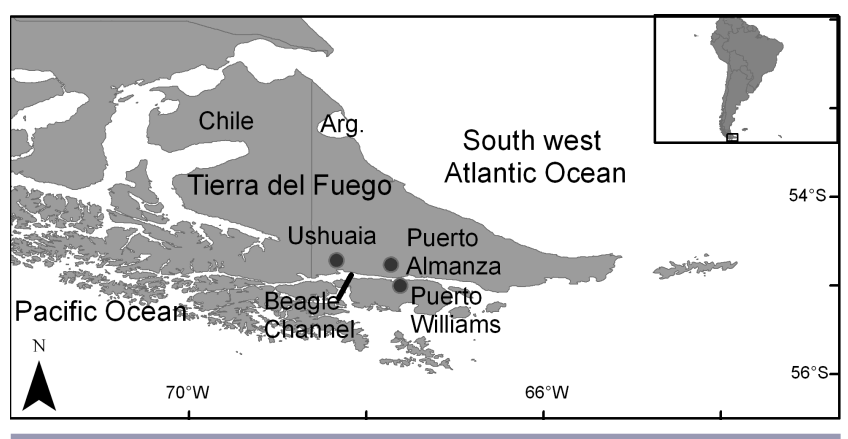

Coupled human and natural systems (CHANS) and the telecoupling approach for human-wildlife interaction research Carter et al.'s (2014) proposal was adapted to analyze the telecouplings of the humans and seabirds found in the $\mathrm{BC}$ - 
Fig. 2. (A) An historical sequence shows how the human subsystem has changed in the Tierra del Fuego Archipelago from 10,000 BP to present. (B) The underlying human-seabird relationship was described over this same time period. (C) Finally, these coupled human and natural systems were evaluated for their telecoupled connections over both space and time.

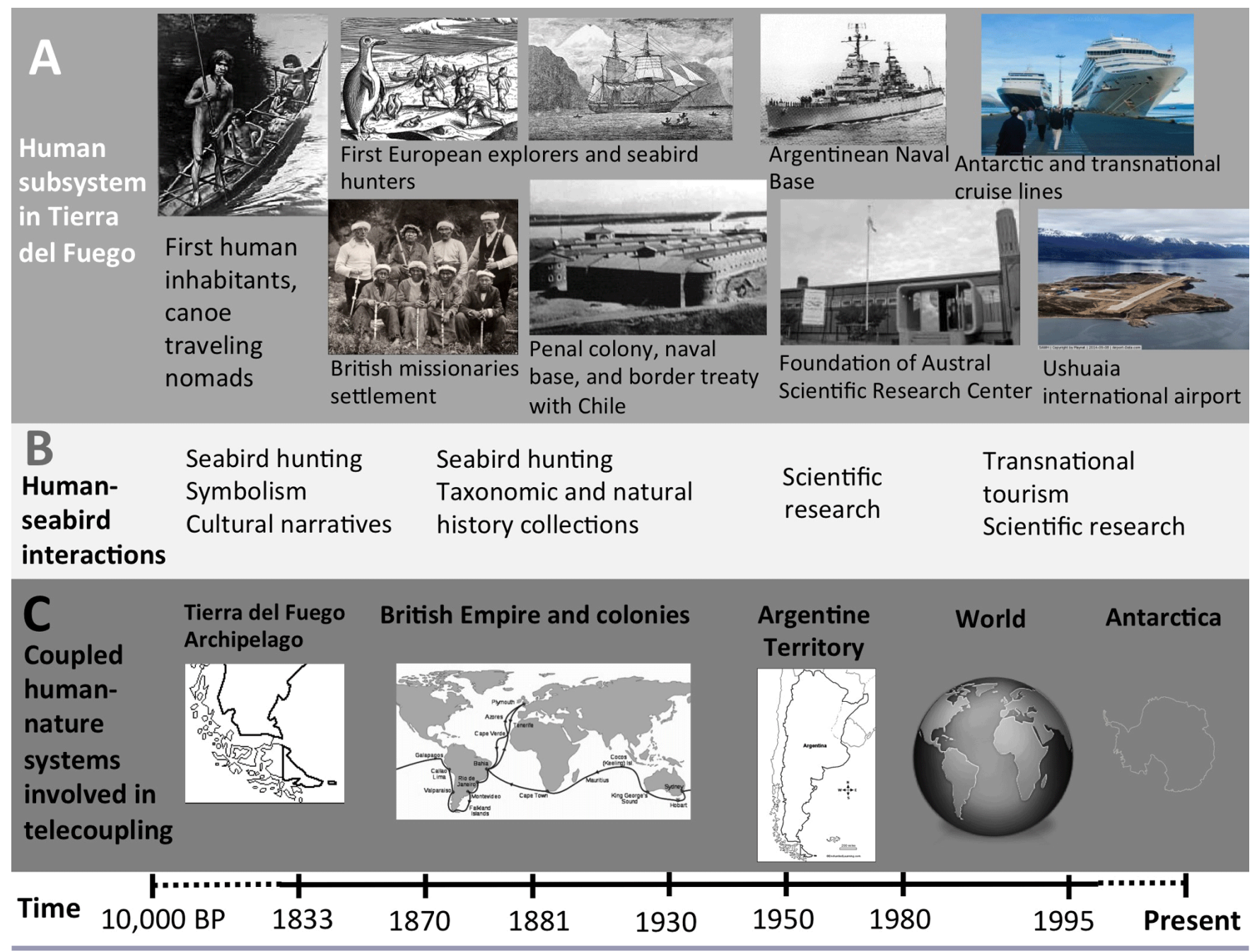

CHANS, using visual representation (Figs. 2, 3) and tables (Table 1). This allows the organization and review of information about the BC's subsystems to identify and assess their components, networks, and interactions. Socioeconomic data were obtained from government and NGO reports, conference proceedings, and historical and social scientific publications. With this information, we tabulated and described the organizations, services, networks, local socioeconomics, and behaviors of the human subsystem. Ecological data were obtained mostly from natural science peerreviewed literature on seabirds to describe the community structure and function, as well as spatial distribution of these species in the natural subsystem.

Although our evaluation seeks to broaden the understanding of humans (Fig. 2 A) and seabirds in the BC over time (Fig. 2 B, C), we centered the analysis on the seabird-tourism interaction as a methodological delimitation of the CHANS(Fig. 3), which would permit greater understanding of extant and ongoing conservation research and policy efforts. For the same reason, we also focused on the Argentine portion of the channel, where tourism is most prevalent and extensively developed and is of a greater economic input to the human subsystem (Figs. 2 A, 3). Finally, we identified the couplings and distance telecouplings that originate from the human-seabird interactions along the $\mathrm{BC}$ (Fig. $2 \mathrm{C}$ ). We then classified and described the five components of this telecoupling. Following Liu et al. (2015), we defined these CHANS subsystems according to the flow of tourists. Finally, key ecological and socioeconomic aspects, which drive the system, were determined and these therefore should be taken into account for effective sustainable tourism development that also ensures nature conservation.

\section{Historical changes in human-seabird relationships in the Beagle Channel}

Archeological and ethno-historical data allowed us to track human-seabird interactions as far back as the earliest human settlement in the archipelago (Fig. 2 A, B, C). The remains of the Shearwater (Puffinus sp.), Southern Giant Petrel (Macronectes 
Fig. 3. Illustration of modern human-seabird relationships in the Beagle Channel (BC):

Tierra del Fuego, Argentina, analyzed as both human and natural subsystems with interactions and telecouplings processes.

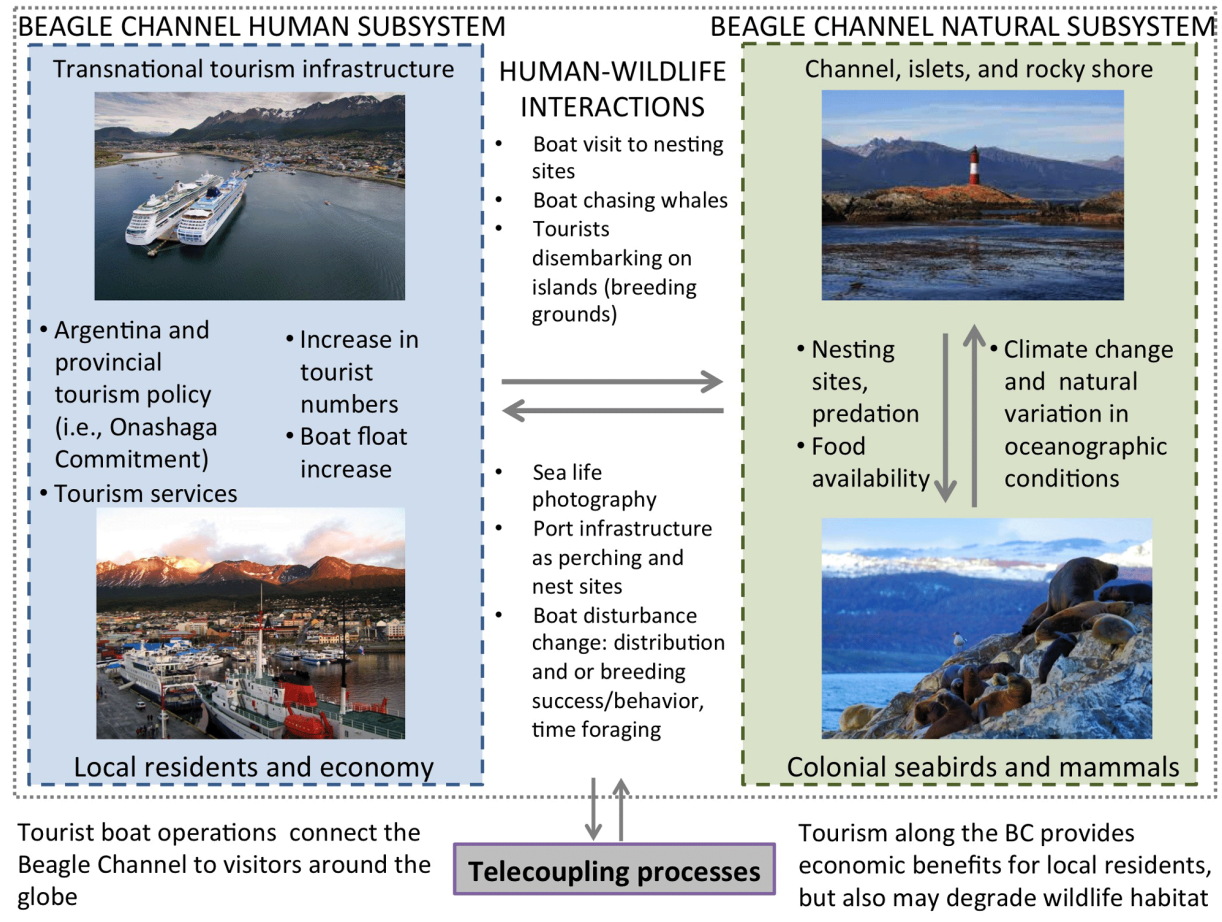

giganteus), Magellanic Penguin (Spheniscus magellanicus), and several species of cormorants (Phalacrocorax spp.) have been found consistently in coastal archeological sites along the BC for both terrestrial (Zangrando et al. 2014) and maritime huntergatherer groups (Orquera and Piana 1999, 2000, Tivoli 2010). These prehistoric societies on and along the BC used birds for various purposes, including subsistence (food), technology (knitting needles and tools), and ornamentation (necklaces), thereby illustrating ancient material and cultural relationships with birds going back 4000-6000 years BP (Tivoli 2010, 2013). Later ethno-historical data from the 19th century are consistent with the archaeological record, documenting these humanseabird relationships for two ethnic groups that inhabited the area. The Yamana were nomadic, maritime hunter-gatherers, who navigated in canoes among the islands, channels, and fjords from the BC to Cape Horn (Fig. 2 A). They fished, hunted, and collected diverse marine, coastal, and terrestrial food, but depended largely on marine mammals and seabirds, including collecting their eggs. The Selk'nam were terrestrial huntergatherers, who only inhabited TDF's main island (Isla Grande) and used coastal resources occasionally to supplement their principal meat source, the Guanaco (Lama guanicoe). Both groups produced rich cultural narratives about birds, including seabirds like albatrosses (Diomedea sp.), cormorants, and penguins (Gusinde 1982). For example, for the Yamana people, albatrosses were not only a source of food and materials, but additionally were powerful symbols of community belonging and were personified as characters in ceremonies and dances (Fiore et al. 2013). In summary, these records demonstrate that early human-seabird interactions linked the $\mathrm{BC}$ with other parts of the archipelago through material and cultural pathways, which were carried out by humans through navigation and terrestrial routes (Fig. 2 A, B, C).

Beginning with Magellan's voyage in the $16^{\text {th }}$ century, southern Patagonia experienced an ever-greater connection to the rest of the Americas, Europe, and other parts of the world via exploiters and explorers (Fig. 2 A). Following the decimation of marine mammals in the northern hemisphere, the TDF archipelago was visited by whalers and sealers starting at the end of the $18^{\text {th }}$ century. These boat-based expeditions sought largely to exploit the meat, oil, and skins of seals and whales, but also extensively hunted penguin colonies for their oil, eggs, and guano, products that were subsequently sent far from the $\mathrm{BC}$ region (Fig. $2 \mathrm{~B}$; Caviglia 2012). This commercial enterprise constitutes the first long-distance telecoupling processes strongly affecting the archipelago, and it continued until the beginning of the $20^{\text {th }}$ century (Caviglia 2012; Fig. 2 C). In the mid-19 $9^{\text {th }}$ century, the BC also underwent a European colonization process in both Argentina and Chile, which was heavily influenced by British explorers and missionaries, as well as gold miners of diverse nationalities, particularly from the Balkan Peninsula such as Croatia (Martinic 2009). The channel was formally "discovered" in 1832 and named by Captain Robert Fitz Roy, aboard the homonymous British navy ship the H.M.S. Beagle (Caviglia 2012). Later, the first permanent European settlement on these shores was an Anglican mission, established in Ushuaia Bay in 1870 (Fig. 2 A; Iparraguirre 2000). These early expeditions 
Table 1. The Beagle Channel (Tierra del Fuego, Argentina) conceived of as a coupled human and natural system (CHANS) with the identification of system components, including economic activities and biological species, presented in order of relevance to the analyzed telecoupling processes.

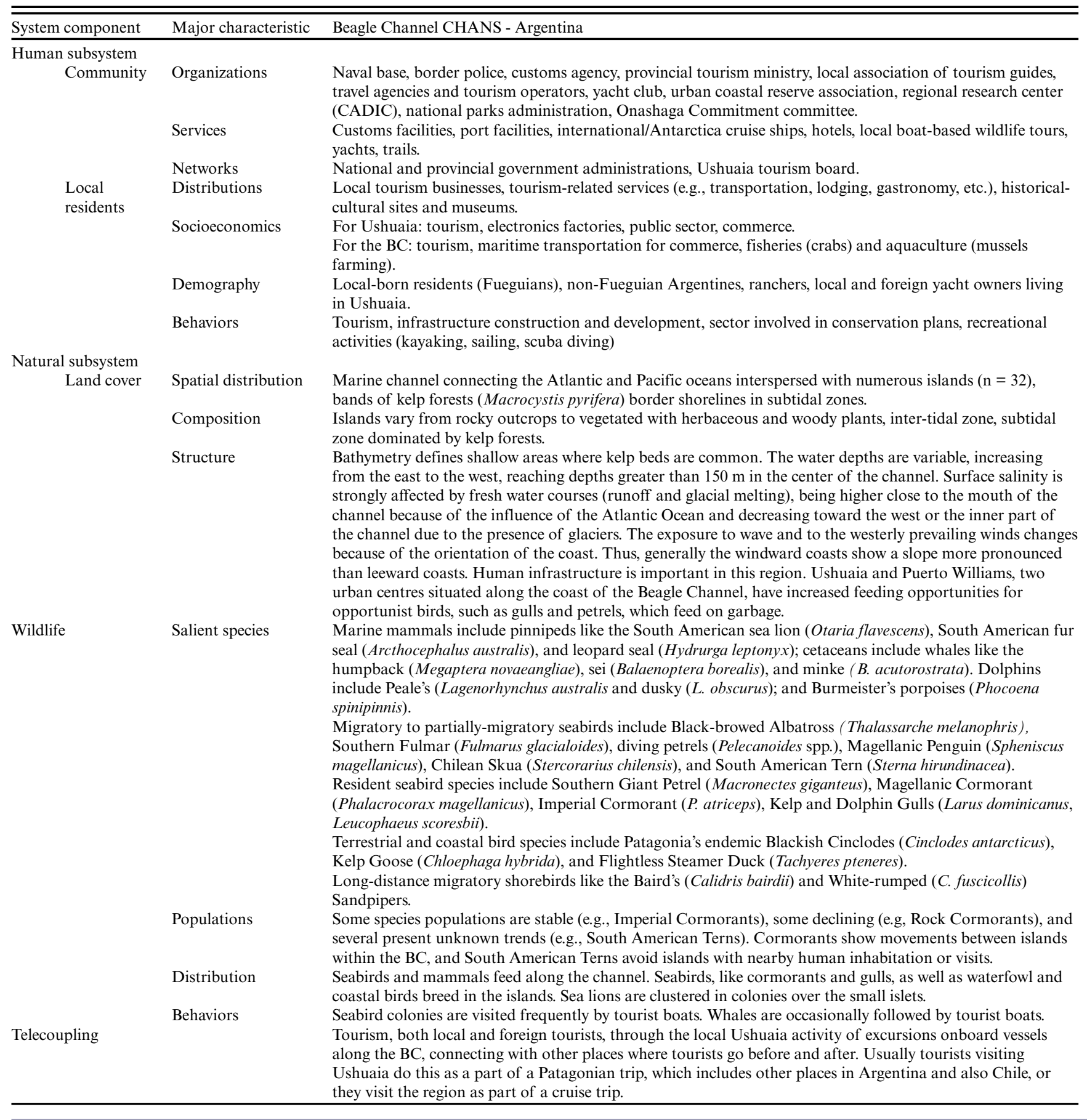

brought influential naturalists, most notably Charles Darwin, into contact with the $\mathrm{BC}$ and initiated an era not only of colonization, but also of wildlife study and specimen collection and description, which introduced a new human-seabird relationship to this territory (Fig. 2 B). Consequently, the BC became teleconnected with the British Empire and other world capitals not only via exploration, immigration, and colonization, but also by way of nascent scientific disciplines that would eventually arise out of natural history (Fig. 2 C; Darwin 1909).

During this period, TDF and the BC in effect were unclaimed geopolitical territories by both Argentina and Chile. Ushuaia was 
officially founded as the capital of the Argentine portion of TDF in 1884 with the establishment of a naval base (van Aert 2013). The town's demographic expansion was slow and based largely on immigrants from Europe, Chile, and other Argentine provinces, who worked for the federal penitentiary built by the national government or in small-scale ranching activities. Human-seabird interactions for this population (e.g., prisoners, miners, ranchers) are poorly documented. It is possible to determine, though, that the BC's human subsystem changed its cultural and ethnic composition, but the national boundaries still were largely theoretical and did not hinder cross-border connectivity and movement of people and commerce between the Argentine and Chilean portions of the channel (Bridges 1949).

In the 1970s, however, tensions arose between the two nations over the sovereignty of three small islands at the mouth of the BC: Picton, Nueva, and Lennox. War was only barely averted, and in 1984 a peace treaty was mediated by the Pope. This episode precipitated a new CHANS condition in the BC by effectively disconnecting the socioeconomic, political, and cultural relationships between the two sides of the channel. At approximately the same time, the Argentine territory was affected by a new law for industrial promotion $(\# 19,640)$, which created financial incentives for the settlement of companies and residents on the island, causing Ushuaia to become a boom town. Its population rose from 313 (indigenous population excluded) in 1895 to 5000 in 1970 , but then expanded exponentially to $\sim 60,000$ by 2010 (van Aert 2013). Consequently, the human subsystem in the Argentine portion of the $\mathrm{BC}$ came to be characterized by rapid growth, expansion of commercial port facilities, and ensuing problems with infrastructure, given the inability to meet the increasing demands of this new population influx and its consequences for the environment (i.e., drinking water provision, sewage treatment, urban deforestation; Braumann and Stadel 1999).

Simultaneous with the financial incentives that increased the island's human population and industrialization, sub-Antarctic/ Antarctic tourism also began to emerge in the late 1970s (Fig. 2 A). At the same time, the Argentine government's National Council for Scientific and Technical Research (CONICET) established the Austral Center of Scientific Research (CADIC), which inaugurated a more formal and permanent era of scientific investigation (and scientific telecouplings) not only for the $\mathrm{BC}$, but also with Antarctica (Fig. 2 C). Together, science and naturebased tourism established a new human-seabird relationship with a new set of actors and interactions that telecoupled the $\mathrm{BC}$ to regional and global scales (Fig. 2 B, C; Rabassa and Borla 2003). Cruise ships started to operate from Ushuaia, with boats from distant places and foreign owners transporting people from all around the world and connecting TDF with the whole continent and other distant countries (Herbert 2014). This economic activity has grown quickly and was accompanied by new infrastructure, such as an expanded airport and maritime port. Tourism in the BC also increased exponentially during this period (Raya Rey et al. 2014). Today, tourism is a principle component of the BC's human subsystem and is focused largely on the natural scenery and wildlife at the end of the world (Figs. 2 C, 3). This economic activity has integrated natural-science research about seabirds, but also includes ancestral and historical narratives about human-nature interactions and relationships in different time periods. As such, the tourism-seabird relationship incorporates both historical and modern coupling between human and natural subsystems.

\section{Identification of key elements of the Beagle Channel as a coupled human and natural system (CHANS)}

\section{Natural subsystem}

The BC's many islands and smaller islets are home to various seabird species, particularly colony-forming species like the Imperial (Pahalocrocorax atriceps) and Rock Cormorants $(P$. magellanicus), Gentoo (Pygoscelis papua) and Magellanic Penguins, and the Kelp Gull (Larus dominicanus; Raya Rey et al. 2014; Table 1). In particular, seabirds are key components of the BC's marine and coastal ecosystems, given their high biomass (Pizarro et al. 2012) and their large effects on trophic relationships in these waters (Raya Rey and Schiavini 2000). Research conducted during the last 20 years by CADIC has shown that population trends vary between species and within and between years. For example, although Rock Cormorant numbers are declining, Magellanic Penguin populations are increasing (Raya Rey et al. 2014). Plus, several waterfowl species, such as the Kelp Goose (Chloephaga hybrida), have become more restricted to small islands and islets in the channel to avoid native and introduced terrestrial predators and other human disturbances that have become greater in the Argentine portion of the $\mathrm{BC}$ (Liljesthröm et al. 2013).

The seabird community found in and along the $\mathrm{BC}$ also displays regional and global connections. For example, the channel is an important area for foraging by pelagic seabirds that additionally use the open ocean and Antarctic waters, such as the Blackbrowed Albatross (Thalassarche melanophires), Southern Fulmar (Fulmarus glacialoides), and the Southern Giant Petrel (Raya Rey and Schiavini 2000). Furthermore, long-distance migratory species, such as the Baird's (Calidris bairdii) and White-rumped Sandpiper (Calidris fuscicollis), breed in the high arctic and winter along the BC's cobble beaches (Moskoff and Montgomerie 2002). Plus, invasive introduced predators have become a particular concern, especially the American mink (Neovison vison), which not only poses a serious conservation threat to seabirds nesting on TDF's coast, but also illustrates the truly global connectivity of humans and other biological species assemblages at the tip of the world (Valenzuela et al. 2014, Ballari et al. 2015).

\section{Human subsystem}

Three human settlements are located along the BC. In Argentina, we find Ushuaia (pop. 60,000) and Puerto Almanza (pop. 20 families), while in Chile the town of Puerto Williams (pop. 2500) lies on the channel's southern shore (Fig. 1). Plus, on both the Chilean and Argentine coasts there are several small ranching operations and military or police outposts. Ushuaia is the area's most prominent city, given its population and also because of the ever-increasing influx of tourists it receives annually, which exceeds its resident population (Raya Rey et al. 2014). Despite being a transoceanic and binational waterway, we described the BC's human subsystem in Argentina, because of the very low level of socio-political integration between the two nations, despite their shared geography. Plus, the two main nature-based tourism activities that occur in the $\mathrm{BC}$ are concentrated in the Argentine portion. Cruise ships navigate the channel and almost exclusively use Ushuaia as their port of departure/arrival or as a port of 
transit (Rozzi el at. 2010). This type of tourism is mainly controlled by foreign capital and headquartered beyond the BC. Catamarans and smaller boats also make daily excursions into the BC and, with one exception in Chile, all are based in Ushuaia.

Employment in Ushuaia is based mainly on government administration $(42 \%)$, but in the private sector tourism leads in jobs created $(15 \%)$, followed by manufacturing $(13 \%)$, construction (10\%), and others (20\%; Herbert 2014). Contrasting with the other economic sectors, tourism has sustained itself largely without governmental subsidies (Herbert 2014) and therefore can be considered an economic activity that could be resilient to adverse local and national political or economic circumstances. Accordingly, tourism has several levels of organization, services, and networks associated with other economic and administrative sectors in Ushuaia's human subsystem (Table 1). For example, tourism vessels and cruise ships interact locally with the Argentine navy and coast guard, as well as with industrial fishing boats that utilize the port infrastructure. To a lesser extent, tourism interacts with local artisanal crabbing boats and mussel aquaculture, which are largely based in Puerto Almanza, $75 \mathrm{~km}$ east of Ushuaia (Table 1).

\section{Human-nature interactions}

Nowadays, the tourism sector has strong and direct relationships with nature generally and wildlife specifically. Navigating to visit the BC's seabird rookeries (and marine mammal colonies) is one of TDF's principle tourism attractions (Fig. 3). By definition, tourism is strongly related to globalization; both have to do with the movement of people, ideas, and capital across borders (Reiser 2003). In keeping with ever greater globalization, the number of visitors arriving to Ushuaia increased by $84 \%$ in just 20 years (1992-2012; Raya Rey et al. 2014) and experienced a further 5\% increase in just the last few years, reaching 298,542 tourists in 2015. Approximately $80 \%$ of these visitors partake in maritime excursions in the BC (Secretaría de Turismo Municipalidad de Ushuaia 2016). Accordingly, the number of tourism boats went from six (with a capacity of about 200 tourists) in 1997 to 25 (with a capacity for more than 2000 tourists) in 2007 (Secretaría de Turismo Municipalidad de Ushuaia 2016).

Larger and more frequent boating activity has a direct impact on marine wildlife (i.e., more islands visited and more places where visitors walk). Concomitantly, tourism infrastructure (i.e., hotels, restaurants) expanded, resulting in greater pollution (e.g., the problem of sewage effluents in Ushuaia's bay eventually lead to the intervention of federal courts) and various impacts and stresses on seabirds. For example, Imperial Cormorants nesting on islets in the navigation route seemed not to be significantly influenced by tourism because their distribution was not affected by visitation nor their breeding success (Rosciano et al. 2013), but Rock Cormorants were found to abandon their nests when boats or sailing vessels approached their colonies to within $100 \mathrm{~m}$ (Schiavini and Yorio 1995). As a result, this population is declining in the BC, and South American Terns (Sterna hirundinacea) entirely avoid nesting on islands within the tourism route (Yorio et al. 2001, Raya Rey et al. 2014).

Although the underlying mechanisms of exactly how humans impact seabirds (and other wildlife) are not entirely clear, many effects are evident. However, there is still a lack of legislation to regulate tourism and protect wildlife. One provincial law (\#176) states that disembarking on islands is prohibited, and no more than one boat at a time can be at the same island. Implementation of this legislation, however, has been subjected to intense pressure from tourism operators and has accomplished little because of a lack of control and enforcement. Nonetheless, the importance and prevalence of nature-based tourism throughout the province leads the stakeholders involved in this activity to be interested in conservation. For these reasons, in 2005, a group of tourist guides, concerned by the increasing numbers of boats and the lack of regulation for visitors approaching nesting areas and disembarking on the islands, initiated a process that led to the "Onashaga Commitment" ("onashaga" is the Yamana name for the BC). This covenant brings together people from the private and public sectors to take actions for better tourism practices, specifically in the BC. It developed 10 recommendations (i.e., a code of conduct) for the crews and tourists who participate in these boat-based excursions. In 2010, these meetings ended with a local certification (Distintivo Onashaga). It was a noteworthy experience; a local certification in which everyone involved in the tourism activity, operators, scientists, and decision makers, each gave their opinion and in this way constructed an agreement that seeks to move toward a sustainable activity (Borla et al. 2010). Currently, renewed financial and political support are required to undertake a rigorous evaluation of the certification program, and without such conditions, the continuation of this socioscientific-political process is in jeopardy.

\section{Detection of telecoupling processes that link the Beagle Channel with other systems}

Of the 298,542 tourists that the $\mathrm{BC}$ receives per year, $60 \%$ come to navigate its waters (53\% domestic, $47 \%$ international; Fig. $4 \mathrm{~A}$ and B; data from Secretaría de Turismo Municipalidad de Ushuaia 2016). Thus, Ushuaia and the BC are the receiving system, whereas the other Argentine provinces, and countries of origin, constitute the sending systems. Domestic tourists come mainly from Buenos Aires (41\%), while Brazilians (26\%) represent the largest share of the international visitors, followed by citizens of the United States (10\%), Canada, Spain, and France (7\% each; Fig. 4 A, B). The spillover systems comprise the other Argentine provinces and countries that tourists visit before and after Ushuaia and the $\mathrm{BC}$, as well as countries that manage the cruise ship industry. Being a faraway destination, Ushuaia and the $\mathrm{BC}$ are usually visited as a part of a longer Argentine or Patagonian trip, which often includes time in Chile. Some travel itineraries encompass the broader South American region and/or use Ushuaia as the starting point for an Antarctic cruise (Huertas et al. 2014). Regarding this aspect, more social research is needed to quantify monetary and capital flows and also to understand the relationship between destinations and the subjective experiences of multinational tourists.

Agents

Agents of telecoupling in the $\mathrm{BC}$ include private tourism companies, such as those who operate boats to navigate the $\mathrm{BC}$, but also other tourism agencies (national and international) that commercialize the excursions. Municipal, provincial, and national government agencies and authorities are responsible for the development and implementation of tourism policies. Ushuaia Bureau, a public-private promotion agency, is made up of government and business entities and was created explicitly to promote tourism (Russo and Darmohraj 2016). Those who 
Fig. 4. (A) Flows of national tourists that come to Ushuaia and connect it with other parts of Argentina and (B) flows of international tourists that come to Ushuaia and connect it with other parts of the world. Totals include: Argentina: 17,963; Latin America: 6912; Europe: 9709; Asia: 10,569; Africa: 95; other parts of the world: 3062. All data are from 2015 and do not include tourists for whom origin was undetermined (Secretaría de Turismo Municipalidad de Ushuaia 2016).

A)

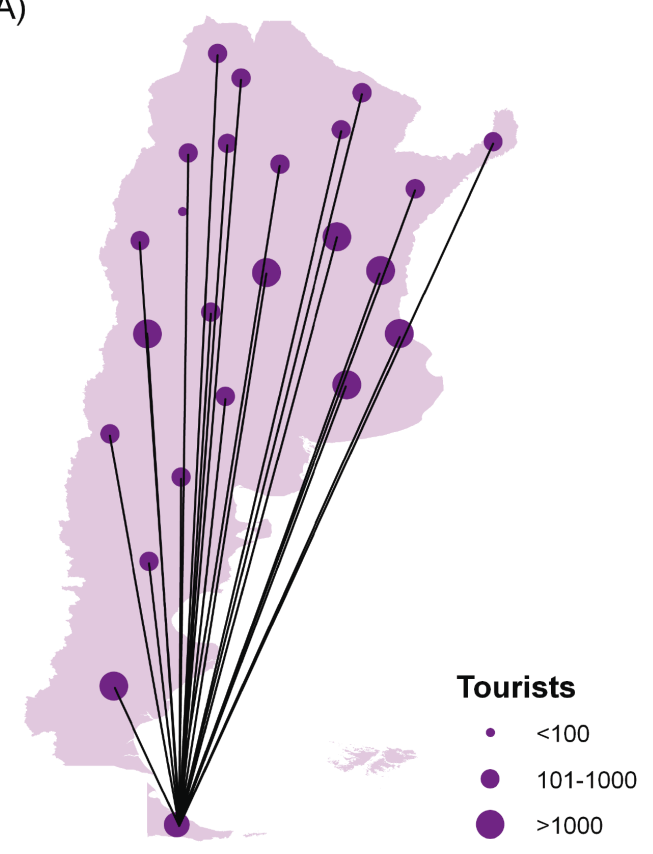

B)

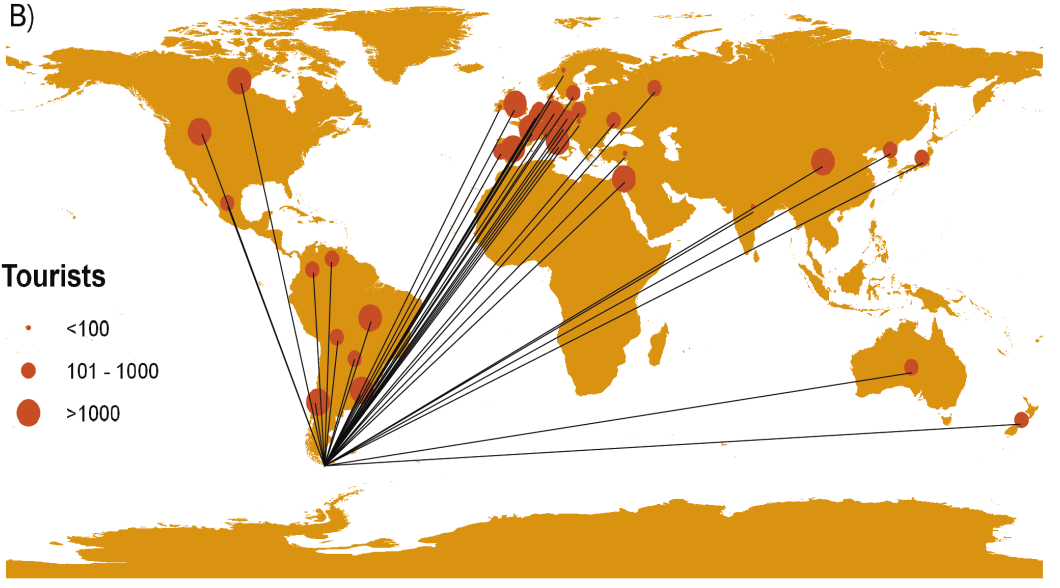

provide services and other excursion possibilities for tourists include guides, ports, customs, the TDF national park, museums, hotels, restaurants, and supply stores. As mentioned, the Onashaga Commitment promotes good practices and wildlife conservation for navigation in the $\mathrm{BC}$ and also brings together public and private stakeholders, including the tourism professionals' association, the national park, CADIC, the provincial tourism agency, tour operators, boat captains, and crew members (Table 1; Fig. 3).

\section{Flows}

Tourists visiting Ushuaia and the $\mathrm{BC}$ come from at least 26 Argentine provinces and 38 countries from all over the world; a number of visitors were not precisely identified by origin (Fig. 4 A, B). Tourism-related finances flow into Ushuaia via travel costs, local consumption, and port taxes. Historical and cultural narratives and ecological information and experiences with wildlife from the $\mathrm{BC}$ and its seabirds constitute a counter-flow toward the visitors' places of origin. Current effects on tourists' knowledge and experiences, based on this counter-flow, have not been measured, but the global impact of historical information and discoveries from the $\mathrm{BC}$ can be traced all the way back to the area's influential role (and portrayal) in Charles Darwin's writings (see Descent of Man, and especially chapters 10 and 11 of the Voyage of the Beagle; Wilson 2006) and subsequent effects on human thinking regarding evolution and other fields of inquiry (Fig. 2 C).
Causes

The drivers of tourism in Ushuaia and the $\mathrm{BC}$, as well as virtually everywhere else in the world include socioeconomic, political, technological, cultural, and environmental factors (Liu et al. 2015). The socioeconomic situation, both in Argentina and in the countries of origin, regulates the amount of tourists that come from distant locations. The promotion of tourism by the private or public sectors at all scales enhances this activity in the $\mathrm{BC}$ (Huertas et al. 2014). Technological advances, particularly communication and transportation, encourage tourism today and make it increasingly accessible and known. The attraction of visiting the end of the world, Patagonia, or the gateway to Antarctica are among the principal reasons to visit the area and constitute a predominant social image held by visitors. Within this context, wildlife and seabirds in particular attract many tourists as either a specific reason for visiting or as part of a broader, nature-based experience. All of this is only possible because of an industrialized world that accumulates disposable time and money for holidays and travel. The mechanisms by which other telecoupled agents or social networks (e.g., web-based tourism companies, blogs, and operators) might participate in these processes (flows and causes of $\mathrm{BC}$ telecoupling) still require further research to quantify these relationships.

\section{Effects}

Tourism has many meaningful effects on Ushuaia's socioeconomic conditions, e.g., increase in employment and 
infrastructure (Wallingre 2004). The increase in tourism-derived income can contribute, however, to an economy whose telecouplings subject it to boom-bust cycles (McGovern et al. 2007). For instance, a change in oil prices or economic recessions in developed countries could be determinant factors for international visitation rates. Currently, the socioeconomic status of TDF (i.e., the industrial proposal law and the economic incentives for residents) has caused a large increase in the BC's resident human population, driven mostly by internal Argentine migration, but if not managed properly this large influx of humans could have catastrophic consequences in both the natural environment and human well-being (Torres et al. 2009). For example, TDF's provincial government and Ushuaia's city council recently lost a court case because for decades they did not invest in the necessary sewer infrastructure to support this transforming social system. Now, the courts have mandated an environmental remediation plan for the bay (see http://cronicasfueguinas. blogspot.com/2014/08/gobierno-y-municipio-ushuaia-condenadoscontaminacion-canal-beagle.html). This case was driven by local citizens, but was also strongly influenced by the tourism sector that perceived this problem as a serious threat for their activities.

Overall, globalization clearly affects the social-ecological system, but how and to what extent depends on its robustness, resilience, vulnerability, and adaptability (Young et al. 2006). International tourism has a noticeable effect to local economies, but it also has an impact on global biogeochemical systems. For example, the carbon footprint of these visits can enhance the climate change that is already affecting polar and subpolar seabirds (Huettmann 2012). More wildlife tourism itself can lead to increased death or injury of animals with varying effects on populations by accidental events, such as vehicle collisions and/or spread of disease (Green and Giese 2004). There could be an impact on wildlife in general and seabirds in particular if tourism increases in an uncontrolled manner or without sufficient legislation and/ or regulation, problems that the Onashaga Commitment seeks to avoid (Borla et al. 2010; Fig. 3). In turn, well-regulated tourism provides an opportunity to enhance a specific cultural ecosystem service provided by seabirds and their marine ecosystems (tourism), but also other contributions of nature are simultaneously maintained, such as food, transportation, nutrient cycling, identity, knowledge, and aesthetic land/seascapes (Burdon et al. 2017). On the other hand, poorly regulated tourism can affect nature's contributions to people, degrading these same benefits via the direct impact of the human visitation or indirect effects like the introduction of invasive exotic flora and fauna (Kirch 1982). The positive and negative environmental and socioeconomic consequences of tourism in the receiving system (e.g., BC, Ushuaia) extend to the spillover cities and countries that tourists visit over their entire journey. In terms of effects within the sending systems, on the one hand, the visit to the $\mathrm{BC}$ is an enriching experience that can be brought back to the place of origin, but at the same time by visiting this remote location, the natural environments in the tourists' home country are also being relieved of pressure to some extent. Nature-based tourism, if done well, can provide benefits to the individual participants in the way of enhanced physical and psychological health as well as educational and conservation outcomes. Higham and Lück (2007) pointed out that on-site benefits of wildlife encounters may also lead to off-site (e.g., in the sending countries) positive outcomes, such as greater environmental awareness and as a consequence can support nature conservation efforts elsewhere.

\section{CONCLUSIONS}

Insights and needs for integrated, multiscale research

This assessment used historical, CHANS, and telecoupling approaches to assess human and seabird relationships in the BC. We not only found that the human-seabird interaction has persisted for 6000 years and continues to be key for human subsistence from socioeconomic and cultural standpoints, but also that this CHANS has always been connected to other systems. Currently, the rapidly growing industry of tourism is a principle process by which humans and seabirds are linked in the BC and between the $\mathrm{BC}$ and the rest of the world.

At the same time, this initial analysis perhaps is of greatest utility for defining and planning a new research agenda of the critical factors and processes involved in couplings and telecouplings of the BC's human and natural subsystems. As such, our diagnosis shows that extant scientific studies on modern seabirds in the BC have focused largely on their biology, and it is only through searching for and synthesizing information from diverse sources, beyond traditional papers, that we are able to construct a more holistic understanding of the aspects that need further investigation. For example, from the well-researched natural subsystem's data, we know there is a need to improve and expand the monitoring and study of the mechanisms of human impact on less-studied seabirds, such as terns, waterfowl, and endemic terrestrial birds (see components Table 1). However, much of the information synthesized and evaluated here for the human subsystem was obtained from grey literature sources (e.g., government agencies) and social science scholarship focused on prehistoric or/ethno-cultural studies that predate the current human-nature relationship. We, therefore, suggest that a priority research need in the $\mathrm{BC}$ is to implement social science and humanities studies that address modern telecoupled thinking on human-nature relationships, trends, and dynamics (see transported "cultural" landscapes in Head 2000). These projects should be integrated into social-ecological models and approaches that recognize and accommodate the imbalance in social theory in these existing interdisciplinary efforts (MacMynowski 2007), benefiting from numerous emerging scientific and policy frameworks that validate the need to provide a deeper and more integrated human-nature and science-society perspective (e.g., the Millennium Ecosystem Assessment, Intergovernmental Platform on Biodiversity and Ecosystem Services, the Stockholm Resilience Alliance).

\section{Threats and opportunities of transnational tourism for conservation}

Our study clearly shows that the BC's human-seabird interactions and connections occurring over long distances have intensified and become increasingly global during the $20^{\text {th }}$ century. Also, the historical growth of the Ushuaia population and the influx of national and international immigrants mean that the current socio-demographic characteristics may inhibit the development of a strong local sense of place with the $\mathrm{BC}$, which has consequences for perceptions and actions regarding the environment and its wildlife. Understanding the modern relationships of urban residents and immigrants is a new 
challenge for environmental psychology and sociology, and further research arising from these standpoints would enhance our understanding of key human dimensions (i.e., local ecological knowledge, sense of place, identity, sustainable behavior) for better practices and governance for reconciling socioeconomic and conservation interests (Pizarro 2015). Indeed, advances in sense of place research show that people can be emotionally attached to several locations (Manzo and Devine-Wright 2014), in a sort of telecoupled sense of place, creating opportunities to positively influence proenvironmental behavior through ex-situ social networks or to explore new forms of governance beyond national borders (Held 2000).

We also can conclude from this assessment that the BC's telecouplings, which became apparent via a specific telecoupled CHANS analysis, are not reflected in its regional integration and transboundary natural resource conservation. Indeed, this shared binational natural subsystem is managed independently by Chile and Argentina without clear efforts for joint administration and governance. The Argentine portion of the $\mathrm{BC}$ has no explicit conservation status with the exception of TDF National Park, while the entire Chilean sector is part of the Cape Horn Biosphere Reserve, which nonetheless has no clear policy for marine protection or any relationship across the border in Argentina. We can say, then, that telecouplings are politically and economically driven or restricted, instead of responding to specific needs of international bird conservation and local social-environmental issues (e.g., sewage management). Accordingly, a telecoupled mindset of international tourism supporting conservation should benefit the adoption of well-known international sustainability certifications, such as those for fisheries (e.g., http://www.msc.org) or forestry (e.g., http://www.fsc.org)), thereby possibly transforming globalization threats into opportunities in our research agenda (Young et al. 2006).

In this context, tourism should be regulated and overseen sufficiently to avoid the $\mathrm{BC}$ from becoming an unintended tragedy of the commons, like the fable popularized by Hardin (1968) in which each neighbor wants to maximize his or her earnings at the expense of the natural system, in this case marine wildlife. If such a scenario were to occur, it would not only affect seabird biodiversity, but also mean a significant deterioration of the social and economic benefits that are derived from tourism. We suggest that a telecoupling analysis allows us to better understand and calculate the capacity and dynamics of this human activity to maintain it as a profitable and long-term human-nature relationship in the $\mathrm{BC}$ and to aid in national and provincial efforts to attain the United Nation's sustainable development goals. In addition, sustainability strategy follows the basic notion of ecosystem carrying capacity (Daly and Farley 2011) and the relevance of a good overall governance framework (Ostrom 1990). As such, authorities could consider options for steady state economic planning that is necessarily based on growth, but rather on increasing benefits and quality to satisfy society's needs and desires (Daly and Farley 2011).

Finally, the threat posed to seabird populations by the exponential growth of the cruise ship industry has previously been recognized (Rozzi et al. 2010). However, this CHANS assessment found that, as shown by the Onashaga Commitment, the private sector can be engaged effectively in conservation and sustainable economic development activities, perhaps providing a foundation for future comanagement strategies for natural resources. However to achieve such ambitious opportunities, the government should reinforce these efforts further via specific legislation, control policies, and incentives that allow its continued monitoring, implementation, and improvement as well as creating the social capital necessary to re-enforce the relationships that are involved in coordinating such an interinstitutional working group. In this context, the telecouplings identified in this study could help to further work together with the spillover systems (especially Chile) to implement regional and global policies (e.g., payment for ecosystem services) that take advantage of nature-based tourists' willingness to support conservation. Different levels of governance (e.g., governmental and nongovernmental organizations) should be desirable for the $\mathrm{BC}$ as a global, shared resource (Ostrom 2009). Also, positive change in tourists and the environment are important for effective management of marine tourism (Higham and Lück 2007).

In closing, recognizing the full potential of these telecoupled systems could help visitors from distant places reduce their impacts and promote proenvironmental behavior on local wildlife tours (Higham and Lück 2007). Integrating these scales into the study and management of the BC would help ensure that humans continue to enjoy and benefit from this unique and charismatic wildlife and at the same time reinforce responsible tourism as a local-global strategy for sustainable development and nature conservation. Future work must quantify these telecoupling processes and others, such as fisheries, to specify the spillover systems and feedback relationships more explicitly. Doing so will allow managers and authorities to enhance the win-win scenarios and trade-off between socioeconomic growth, human development, and environmental sustainability.

Responses to this article can be read online at: http://www.ecologyandsociety.org/issues/responses. $\mathrm{php} / 9771$

\section{Acknowledgments:}

We thank CONICET for institutional support, particularly PUE 2016 Sinergias y conflictos entre las actividades económicas y los socio-ecosistemas de Tierra del Fuego: Mantenimiento de la productividad y los servicios ecosistémicos en el largo plazo and CADIC's Grupo de Estudios Socio-Ecológicos. Also ARR acknowledges a NASA-MSU award and a grant from the Agencia para la Promoción de la Ciencia y la Tecnología (PICT 2012 \#1832) that allowed participation in the Telecoupling Workshop and Symposium, hosted by Drs. J. Liu and V. Hull, at the International Association for Landscape Ecology Meeting in April 2016. JCP was supported by a Latin American Postdoctoral Fellowship from CONICET.

\section{LITERATURE CITED}

Adger, W. N., H. Eakin, and A. Winkels. 2009. Nested and teleconnected vulnerabilities to environmental change. Frontiers in Ecology and the Environment 7(3):150-157. http://dx.doi. org/10.1890/070148 
Ballari, S. A., M. F. Cuevas, S. Cirignoli, and A. E. J. Valenzuela. 2015. Invasive wild boar in Argentina: using protected areas as a research platform to determine distribution, impacts and management. Biological Invasions 17(6):1595-1602. http://dx.doi. org/10.1007/s10530-014-0818-7

Borla, M. L., S. Kizman, and A. Raya Rey. 2010. Compromiso Onashaga. Una experiencia sobre turismo y conservación. La fauna del canal Beagle como recurso vulnerable (In Spanish). [online] URL: http://www.cadic-conicet.gob.ar/wp-content/uploads/2016/11/ Onashaga-Borla-et-al.-2010.pdf

Braumann, V., and C. Stadel. 1999. Boom town in transition? Development process and urban structure of Ushuaia, Tierra del Fuego, Argentina. Yearbook Conference of Latin Americanist Geographers 25:33-44. [online] URL: http://www.jstor.org/ stable/25765873

Bridges, E. L. 1949. Uttermost part of the world: the first history of Tierra del Fuego and the Fuegian Indians. EP Dutton and Co., New York, New York, USA.

Burdon, D., T. Potts, C. Barbone, and L. Mander. 2017. The matrix revisited: a bird's-eye view of marine ecosystem service provision. Marine Policy 77:78-89. http://dx.doi.org/10.1016/j. marpol.2016.12.015

Carter, N. H., A. Viña, V. Hull, W. J. McConnell, W. Axinn, D. Ghimire, and J. Liu. 2014. Coupled human and natural systems approach to wildlife research and conservation. Ecology and Society 19(3):43. http://dx.doi.org/10.5751/ES-06881-190343

Caviglia, S. E. 2012. Malvinas: Soberanía, Memoria y Justicia: 10 de Junio de 1829. First edition. Ministerio de Educación de la Provincia de Chubut, Rawson, Chubut, Argentina.

Crutzen, P. J. 2002. Geology of mankind. Nature 415(6867):23. http://dx.doi.org/10.1038/415023a

Daly, H. E., and J. C. Farley. 2011. Ecologicaleconomics: principles and applications. Island, Washington, D.C., USA. http://dx.doi. org/10.1126/science.254.5030.358-a

Darwin, C. 1909. Voyage of the Beagle. Collier, New York, New York, USA. http://dx.doi.org/10.5962/bhl.title.98662

Descamps, S., J. Aars, E. Fuglei, K. M. Kovacs, C. Lydersen, O. Pavlova, À. Ø. Pedersen, V. Ravolainen, and H. Strøm. 2017. Climate change impacts on wildlife in a High Arctic archipelago - Svalbard, Norway. Global Change Biology 23:490-502.

Di Giacomo, A. S., M. V. De Francesco, and E. G. Coconier. 2007. Áreas importantes para la conservación de las aves en Argentina. Sitios prioritarios para la conservación de la biodiversidad. Temas de Naturaleza y Conservación. Aves Argentinas, Asociación ornitológica de La Plata, Buenos Aires, Argentina.

Eakin, H., R. DeFries, S. Kerr, E. F. Lambin, J. Liu, P. J. Marcotullio, P. Messerli, A. Reenberg, X. Rueda, S. R. Swaffield, B. Wicke, and K. Zimmerer. 2014. Significance of telecoupling for exploration of land-use change. Pages 141-162 in K. C. Seto, and A. Reenberg, editors. Rethinking global land use in an urban era. MIT Press, Cambridge, Massachusetts, USA. http://dx.doi. org/10.7551/mitpress $/ 9780262026901.003 .0008$
Ferreira, A. M., J. C. Marques, and S. Seixas. 2017. Integrating marine ecosystem conservation and ecosystems services economic valuation: implications for coastal zones governance. Ecological Indicators 77:114-122. http://dx.doi.org/10.1016/j. ecolind.2017.01.036

Fiore, D., A. Tivoli, and A. F. Zangrando. 2013. Is the environment good to eat or good to paint? Faunal consumption and avoidance among hunter-gatherer-fishers in the Beagle Channel Region (Tierra del Fuego, South America). Pages 77-96 in M. I. J. Davies and F. N. M'Mbogori, editors. Humans and the environment: new archaeological perspectives for the twenty-first century. Oxford University Press, Oxford, UK.

Frenot, Y., S. L. Chown, J. Whinam, P. M. Selkirk, P. Convey, M. Skotnicki, and D. M. Bergstrom. 2005. Biological invasions in the Antarctic: extent, impacts and implications. Biological reviews of the Cambridge Philosophical Society 80(1):45-72. http://dx.doi. org/10.1017/S1464793104006542

Green, R., and M. Giese. 2004. Negative effects of wildlife tourism on wildlife. Pages 81-97 in K. Higginbottom, editor. Wildlife tourism: impacts, management and planning. CRC for Sustainable Tourism and Common Ground Publishing, Altona, Illinois, USA.

Gusinde, M. 1982. Los Selk'nam. Los indios de Tierra del Fuego. Tomo I. Centro Argentino de Etnología Americana, Buenos Aires, Argentina.

Hardin, G. 1968. The tragedy of the commons. Science 162:1243-1248. http://dx.doi.org/10.1126/science.162.3859.1243

Head, L. 2000. Cultural landscapes and environmental change. Arnold, London, UK.

Held, D. 2000. Regulating globalization? The reinvention of politics. International Sociology 15(2):394-408. http://dx.doi. org/10.1177/0268580900015002015

Held, D., A. McGrew, D. Goldblatt, and J. Perraton. 1999. Global transformations. Stanford University Press, Redwood City, California, USA.

Herbert, A. 2014. Making place at the end of the world: an ethnography of tourism and urban development in Ushuaia, Argentina's Antarctic gateway city. Dissertation. University of Canterbury, Christchurch, New Zealand. [online] URL: https:// ir.canterbury.ac.nz/handle/10092/9421

Higham, J. E., and M. Lück. 2007. Marine wildlife and tourism management: insights from the natural and social sciences. Centre for Agriculture and Biosciences International (CABI), Wallingford, Oxfordshire, Uk. http://dx.doi.org/10.1079/978184$\underline{5933456.0000}$

Huertas, F. O., N. S. Elizondo, A. L. González, S. E. Chenlo, Á A. Gottig, A. M. Robledo, R. Frías, and A. V. Arcos. 2014. Informe de avance del proyecto de investigación-979/2012 FHCS-SUUNPSJB: indicadores que favorecieron el desarrollo local de la actividad económica del turismo en la ciudad de Ushuaia, provincia de Tierra del Fuego Antártida e Islas del Atlántico Sur, Argentina, en el período 1985/2010. Libro de actas VI Congreso Latinoamericano de Investigación Turística. 1st edition. EDUCO 
- Facultad de Turismo. Universidad Nacional del Comahue. Neuquén, Argentina. http://170.210.83.98:8080/jspui/ handle/123456789/462

Huettmann, F. 2012. Protection of the three poles. Springer, New York, New York, USA. http://dx.doi.org/10.1007/978-4-431-54006-9

Iparraguirre, S. 2000. Tierra del Fuego: una biografía del fin del mundo. Editorial El Ateneo, Buenos Aires, Argentina.

Kirch, P. V. 1982. Transported landscapes. Natural History 91 (12):32-35.

Lambin, E. F., and P. Meyfroidt. 2011. Global land use change, economic globalization, and the looming land scarcity. Proceedings of the National Academy of Sciences 108 (9):3465-3472. http://dx.doi.org/10.1073/pnas.1100480108

Lewis, P. N., M. J. Riddle, and C. L. Hewitt. 2004. Management of exogenous threats to Antarctica and the sub-Antarctic islands: balancing risks from TBT and non-indigenous marine organisms. Marine Pollution Bulletin 49(11):999-1005. http://dx.doi. org/10.1016/j.marpolbul.2004.07.001

Liljesthröm, M., A. Schiavini, R. A. Sáenz Samaniego, L. Fasola, and A. Raya Rey. 2013. Kelp geese (Chloephaga hybrida) and flightless steamer-ducks (Tachyeres pteneres) in the Beagle Channel: the importance of islands in providing nesting habitat. Wilson Journal of Ornithology 125(3):583-591. http://dx.doi. org/10.1676/13-028.1

Liu, J. 2014. Forest sustainability in China and implications for a telecoupled world. Asia and the Pacific Policy Studies 1:230-250. http://dx.doi.org/10.1002/app5.17

Liu, J., T. Dietz, S. R. Carpenter, M. Alberti, C. Folke, E. Moran, A. N. Pell, P. Deadman, T. Kratz, J. Lubchenco, E. Ostrom, Z. Ouyang, W. Provencher, C. L. Redman, S. H. Schneider, and W. W. Taylor. 2007. Complexity of coupled human and natural systems. Science 317(5844):1513-1516. http://dx.doi.org/10.1126/ science. 1144004

Liu, J., V. Hull, M. Batistella, R. Defries, T. Dietz, F. Fu, T. W. Hertel, R. Cesar, E. F. Lambin, S. Li, L. A. Martinelli, W. J. Mcconnell, E. F. Moran, R. Naylor, Z. Ouyang, K. R. Polenske, A. Reenberg, G. de Miranda Rocha, C. S. Simmons, P. H. Verburg, P. M. Vitousek, F. Zhang, and C. Zhu. 2013. Framing sustainability in a telecoupled world. Ecology and Society 18 (2):26. http://dx.doi.org/10.5751/ES-05873-180226

Liu, W., C. A. Vogt, F. Lupi, G. He, Z. Ouyang, and J. Liu. 2015. Evolution of tourism in a flagship protected area of China. Journal of Sustainable Tourism 24(2):203-226. http://dx.doi. org/10.1080/09669582.2015.1071380

Lonely Planet. 2016. Introducing Ushuaia. Lonely Planet, Melbourne, Victoria, Australia. [online] URL: http://www. lonelyplanet.com/argentina/tierra-del-fuego/ushuaia/introduction

Lück, M., P. T. Maher, and E. J. Stewart. 2010. Cruise tourism in Polar regions: promoting environmental and social sustainability? Earthscan, London, UK and Washington, D.C., USA.

Lüdecke, C. 2010. Gorgeous landscapes and wildlife: the importance and danger of antarctic tourism. Estudios Hemisféricos y Polares 1(4):1-19.
MacMynowski, D. P. 2007. Pausing at the brink of interdisciplinarity: power and knowledge at the meeting of social and biophysical science. Ecology and Society 12(1):20 http://dx. doi.org/10.5751/ES-02009-120120

Manzo, L. C., and P. Devine-Wright. 2014. Place attachment: advances in theory, methods and applications. Routledge, New York, New York, USA.

Martinic, B. 2009. Relations and trade between Magellan Territory and Falkland Islands (1845-1950). Magallania 37 (2):5-21.

McGovern, T. H., O. Vésteinsson, A. Fridriksson, M. Church, I. Lawson, I. A. Simpson, A. Einarsson, A. Dugmore, G. Cook, S. Perdikaris, K. J. Edwards, A. M. Thomson, W. P. Adderley, A. Newton, G. Lucas, R. Edvardsson, O. Aldred, and E. Dunbar. 2007. Landscapes of settlement in northern Iceland: historical ecology of human impact and climate fluctuation on the millennial scale. American Anthropologist 109:27-51. http://dx. doi.org/10.1525/aa.2007.109.1.27

Millennium Ecosystem Assessment (MEA). 2003. Ecosystems and human well-being: a framework for assessment. Island, Washington, D.C., USA. [online] URL: http://pdf.wri.org/ ecosystems human_wellbeing.pdf

Mittermeier, R. A., C. G. Mittermeier, T. M. Brooks, J. D. Pilgrim, W. R. Konstant, G. A. B. da Fonseca, and C. Kormos. 2003. Wilderness and biodiversity conservation. Proceedings of the National Academy of Sciences 100(18):10309-10313. http://dx. doi.org/10.1073/pnas. 1732458100

Moskoff, W., and R. Montgomerie. 2002. Baird's sandpiper (Calidris bairdii). Page 661 in A. Poole, editor. The birds of North America online. Cornell Lab of Ornithology, Ithaca, New York, USA. [online] URL: https://birdsna.org/Species-Account/bna/ species/baisan/introduction http://dx.doi.org/10.2173/bna.661

Moss, C. 2014. Patagonia: a cultural history. Landscapes of the imagination series. Signal, Oxford, UK.

Nahuelhual, L., X. Vergara, A. Kusch, G. Campos, and D. Droguett. 2017. Mapping ecosystem services for marine spatial planning: recreation opportunities in Sub-Antarctic Chile Marine Policy 81:211-218. http://dx.doi.org/10.1016/j.marpol.2017.03.038

Ostrom, E. 1990. Governing the commons: the evolution of institutions for collective action. Cambridge University Press, Cambridge, UK.

Ostrom, E. 2009. A general framework for analyzing sustainability of social-ecological systems. Science 325 (5939):419-422. http://dx.doi.org/10.1126/science.1172133

Orquera, L. A., and E. L. Piana. 1999. Arqueología de la región del canal Beagle (Tierra del Fuego, República Argentina). Sociedad Argentina de Antropología, Buenos Aires, Argentina.

Orquera, L. A., and E. L. Piana 2000. Composición de Conchales de la costa del canal Beagle (Tierra del Fuego, República Argentina) Primera parte. Relaciones de la Sociedad Argentina de Antropología 25:249-274.

Pizarro, J. C. 2015. Feathered roots and migratory routes: Latin American immigrants and birds. Dissertation. Environment and 
Resource Studies, University of Waterloo, Ontario, Canada. [online] URL: https://uwspace.uwaterloo.ca/handle/10012/10081

Pizarro, J. C., C. B. Anderson, and R. Rozzi. 2012. Birds as marineterrestrial linkages in sub-polar archipelagic systems: avian community composition, function and seasonal dynamics in the Cape Horn Biosphere Reserve (54-55 S), Chile. Polar Biology 35 (1):39-51. http://dx.doi.org/10.1007/s00300-011-1029-7

Rabassa, J., and M. L. Borla. 2003. Antarctic Peninsula and Tierra del Fuego: 100 years of Swedish-Argentine scientific cooperation at the end of the world: proceedings of Otto Nordensjold's Antarctic expedition of 1901-1903 and Swedish scientists in Patagonia: a symposium. March 2-7, 2003, Buenos Aires, Argentina. CRC Press, Boca Raton, Florida, USA.

Raya Rey, A., N. Rosciano, M. Liljesthröm, R. Sáenz Samaniego, and A. Schiavini. 2014. Species-specific population trends detected for penguins, gulls and cormorants over 20 years in subAntarctic Fuegian Archipelago. Polar Biology 37(9):1343-1360. http://dx.doi.org/10.1007/s00300-014-1526-6

Raya Rey, A., and A. C. M. Schiavini. 2000. Distribution, abundance and associations of seabirds in the Beagle Channel, Tierra del Fuego, Argentina. Polar Biology 23(5):338-345. http:// dx.doi.org/10.1007/s003000050453

Reiser, D. 2003. Globalisation: an old phenomenon that needs to be rediscovered for tourism? Tourism and Hospitality Research 4 (4):306-320. http://dx.doi.org/10.1177/146735840300400404

Reyes-Arriagada, R., P. P. Schlatter, P. J. Hodum, and R. Rozzi. 2015. Seabirds and islands communities: biodiversity awareness as a tool for the conservation of insular species. Pages 23-45 in G. Mahala, editor. Seabirds and songbirds: habitat preferences, conservation and migratory behavior. Nova, Hauppauge, New York, USA.

Rosciano, N. G., W. S. Svagelj, and A. Raya Rey. 2013. Effect of anthropic activity on the imperial cormorants and rock shags colonies in the Beagle Channel, Tierra del Fuego. Revista de biología marina y oceanografía 48(1):165-176. http://dx.doi. org/10.4067/S0718-19572013000100014

Rozzi, R. J., J. R. Armesto, J. Gutiérrez, F. Massardo, G. E. Likens, C. B. Anderson, A. Poole, K. P. Moses, E. Hargrove, A. O. Mansilla, J. H. Kennedy, M. Willson, K. Jax, C. G. Jones, J. B. Callicott, and M. T. K. Arroyo. 2012. Integrating ecology and environmental ethics: earth stewardship in the southern end of the Americas. BioScience 62(3):226-236. https://doi.org/10.1525/ bio.2012.62.3.4

Rozzi, R., F. Massardo, and C. B. Anderson. 2004. The Cape Horn Biosphere Reserve: a proposal for conservation and tourism to achieve sustainable development at the southern end of the Americas. Ediciones Universidad de Magallanes, Punta Arenas, Chile.

Rozzi, R., F. Massardo, F. Cruz, C. Grenier, A. Muñoz, E. Mueller, and J. Elbers. 2010. Galápagos and Cape Horn: ecotourism or green-washing in two iconic Latin American archipelagoes. Environmental Philosophy 7(2):1-32. http://dx.doi. org/10.5840/envirophil20107213
Russo, N. E., and A. Darmohraj. 2016. Colaboración públicoprivada en turismo. Capacidades institucionales en partenariados de gestión turística local en Argentina. Revista del CLAD Reforma y Democracia 65:157-192.

Schiavini, A. C. M., and A. Raya Rey. 2001. Aves y mamíferos marinos en Tierra del Fuego: estado de situación, interacción con actividades humanas y recomendaciones para su manejo. Fundación Patagonia Natural, Puerto Madryn, Argentina.

Schiavini, A., and Yorio, P. 1995. Distribution and abundance of seabird colonies in the Argentine sector of the Beagle Channel, Tierra del Fuego. Marine Ornithology 23(1):39-46. [online] URL: http://www.marineornithology.org/PDF/23 1/MO 1995 06.pdf

Secretaria de Turismo Municipalidad de Ushuaia. 2016. Informes estadísticos. Secretaria de Turismo Municipalidad de Ushuaia, [online] URL: http://www.turismoushuaia.com/en/about-ushuaia/ turismo-en-numeros

Steadman, D. W. 1995. Prehistoric extinctions of Pacific island birds: biodiversity meets zooarchaeology. Science 267 (5201):1123-1131. http://dx.doi.org/10.1126/science.267.5201.1123

Tin, T., D. Liggett, P. T. Maher, and M. Lamers. 2016. Antarctic futures: human engagement with the Antarctic environment. Springer, New York, New York, USA. http://dx.doi. org/10.1007/978-94-007-6582-5

Tivoli, A. M. 2010. Exploitation of bird resources among prehistoric sea-nomad societies of the Beagle Channel region, southern South America. Before Farming 2:1-12. http://dx.doi. org/10.3828/bfarm.2010.2.3

Tivoli, A. M. 2013. Aprovechamiento de materias primas óseas de aves para la confección de punzones huecos en la región del canal Beagle. Intersecciones en Antropología14:251-262. [online] URL: http://www.scielo.org.ar/scielo.php?script=sci arttext\&pid= $\underline{\text { S1850-373X2013000100016 }}$

Torres, A. I., M. N. Gil, O. A. Amín, and J. L. Esteves. 2009. Environmental characterization of a eutrophicated semi-enclosed system: nutrient budget (Encerrada Bay, Tierra del Fuego Island, Patagonia, Argentina). Water, Air, and Soil Pollution 204 (1-4):259-270. http://dx.doi.org/10.1007/s11270-009-0042-8

Valenzuela, A. E. J., C. B. Anderson, L. Fasola, and J. L. Cabello. 2014. Linking invasive exotic vertebrates and their ecosystem impacts in Tierra del Fuego to test theory and determine action. Acta Oecologica 54:110-118. http://dx.doi.org/10.1016/j.actao.2013.01.010

van Aert, P. 2013. Tierra del Fuego. Pages 195-211 in G. Baldacchino, editor. The political economy of divided islands. Unified geographies, multiple polities. Palgrave Macmillan, Basinsgtone, Hampshire, UK.

Walker, B., C. S. Holling, S. R. Carpenter, and A. Kinzig. 2004. Resilience, adaptability and transformability in social-ecological systems. Ecology and Society 9(2):5. http://dx.doi.org/10.5751/ ES-00650-090205

Wallingre, N. 2004. El turismo como factor de reconversión productiva local en la ciudad de Ushuaia, República Argentina. Turismo y Sociedad 3:86-95. [online] URL: http://revistas. uexternado.edu.co/index.php/tursoc/article/view/2227/1971 
Whelan, C. J., D. G. Wenny, and R. J. Marquis. 2008. Ecosystem services provided by birds. Annals of the New York Academy of Sciences 1134(1):25-60. http://dx.doi.org/10.1196/annals.1439.003

Wilson, E. O. 2006. From so simple a beginning: the four great books of Charles Darwin. First edition. W. W. Norton and Company, New York, New York, USA.

Yorio, P., E. Frere, P. Gandini, and A. Schiavini. 2001. Tourism and recreation at seabird breeding sites in Patagonia, Argentina: current concerns and future prospects. Bird Conservation International 11(4):231-245. http://dx.doi.org/10.1017/

S0959270901000314

Young, O. R., F. Berkhout, G. C. Gallopin, M. A. Janssen, E. Ostrom, and S. Van der Leeuw. 2006. The globalization of socioecological systems: an agenda for scientific research. Global Environmental Change 16(3):304-316. http://dx.doi.org/10.1016/ j.gloenvcha.2006.03.004

Zangrando, A. F., K. B. Borrazzo, A. M. Tivoli, D. V. Alunni, and M. P. Martinoli. 2014. El sitio Heshkaia 35: nuevos datos sobre la arqueología de Moat (Tierra del Fuego, Argentina)/ Heshkaia 35 site: new data on the archaeology of Moat (Tierra del Fuego, Argentina). Revista del Museo de Antropologia. 7:11-24. 